Research article

\title{
A framework for engaging stakeholders on the management of alien species
}

\author{
Ana Novoa a, b, c, *, Ross Shackleton ${ }^{\text {a }}$, Susan Canavan ${ }^{\mathrm{a}, \mathrm{b}}$, Cathleen Cybèle ${ }^{\mathrm{d}, \mathrm{e}}$, \\ Sarah J. Davies ${ }^{a}$, Katharina Dehnen-Schmutz ${ }^{f}$, Jana Fried ${ }^{\mathrm{f}}$, Mirijam Gaertner ${ }^{\mathrm{a}, \mathrm{g}}$, \\ Sjirk Geerts ${ }^{\text {h }}$, Charles L. Griffiths ${ }^{\mathrm{i}, \mathrm{j}}$, Haylee Kaplan ${ }^{\mathrm{b}}$, Sabrina Kumschick ${ }^{\mathrm{a}, \mathrm{b}}$, \\ David C. Le Maitre ${ }^{\mathrm{k}}$, G. John Measey a, Ana L. Nunes ${ }^{\mathrm{a}, \mathrm{b}, \mathrm{l}}$, David M. Richardson ${ }^{\mathrm{a}}$, \\ Tamara B. Robinson ${ }^{a}$, Julia Touza ${ }^{\mathrm{m}}$, John R.U. Wilson ${ }^{\mathrm{a}, \mathrm{b}}$
}

${ }^{a}$ Centre for Invasion Biology, Department of Botany and Zoology, Stellenbosch University, Matieland, South Africa

${ }^{\mathrm{b}}$ South African National Biodiversity Institute, Kirstenbosch Research Centre, Claremont, South Africa

${ }^{c}$ Institute of Botany, Department of Invasion Ecology, The Czech Academy of Sciences, CZ-252 43, Prühonice, Czech Republic

d CIRAD, UMR PVBMT, Saint-Pierre, La Réunion, France

e Université de la Réunion, UMR PVBMT, F-97410, Saint-Pierre, La Réunion, France

${ }^{\mathrm{f}}$ Centre for Agroecology, Water and Resilience, Coventry University, Ryton Gardens, Wolston Lane, Coventry, CV8 3LG, UK

${ }^{g}$ Nürtingen-Geislingen University of Applied Sciences (HFWU), Nürtingen, Germany

${ }^{\mathrm{h}}$ Department Conservation and Marine Science, Cape Peninsula University of Technology, P.O. Box 652, Cape Town, 8000, South Africa

${ }^{\mathrm{i}}$ Marine Research (MA-RE) Institute, University of Cape Town, Private Bag X3, Rondebosch, 7701, South Africa

${ }^{\mathrm{j}}$ Department of Biological Sciences, University of Cape Town, Private Bag X3, Rondebosch, 7701, South Africa

${ }^{\mathrm{k}}$ Council for Industrial and Scientific Research, P.O. Box 320, Stellenbosch, 7599, South Africa

${ }^{1}$ South African Institute for Aquatic Biodiversity, Grahamstown, South Africa

${ }^{\mathrm{m}}$ Environment Department, Wentworth Way, University of York, Heslington, York, YO10 5NG, UK

\section{A R T I C L E I N F O}

\section{Article history:}

Received 20 December 2016

Received in revised form

20 September 2017

Accepted 21 September 2017

\section{Keywords:}

Biological invasions

Conflicts of interests

Invasive species management

Perceptions

Stakeholder ownership

Environmental management

\begin{abstract}
A B S T R A C T
Alien species can have major ecological and socioeconomic impacts in their novel ranges and so effective management actions are needed. However, management can be contentious and create conflicts, especially when stakeholders who benefit from alien species are different from those who incur costs. Such conflicts of interests mean that management strategies can often not be implemented. There is, therefore, increasing interest in engaging stakeholders affected by alien species or by their management. Through a facilitated workshop and consultation process including academics and managers working on a variety of organisms and in different areas (urban and rural) and ecosystems (terrestrial and aquatic), we developed a framework for engaging stakeholders in the management of alien species. The proposed framework for stakeholder engagement consists of 12 steps: (1) identify stakeholders; (2) select key stakeholders for engagement; (3) explore key stakeholders' perceptions and develop initial aims for management; (4) engage key stakeholders in the development of a draft management strategy; (5) reexplore key stakeholders' perceptions and revise the aims of the strategy; (6) co-design general aims, management objectives and time frames with key stakeholders; (7) co-design a management strategy; (8) facilitate stakeholders' ownership of the strategy and adapt as required; and (9) implement the strategy and monitor management actions to evaluate the need for additional or future actions. In case additional management is needed after these actions take place, some extra steps should be taken: (10) identify any new stakeholders, benefits, and costs; (11) monitor engagement; and (12) revise management strategy. Overall, we believe that our framework provides an effective approach to minimize the impact of conflicts created by alien species management.
\end{abstract}

(๑) 2017 Elsevier Ltd. All rights reserved.

\footnotetext{
* Corresponding author.

E-mail address: novoa.perez.ana@gmail.com (A. Novoa).
}

\section{Introduction}


outside their native ranges. This has been done for a range of reasons including purposefully for agriculture, aquaculture, forestry, ornamental horticulture, the pet trade, and recreation; and accidentally through ballast water, fouling or concealment in transported goods (Mack, 2003). Many of these introductions were, and remain, desirable (indeed indispensable) for humans, and include the staple food crops in most countries. These can be called "desirable species" due to the benefits they provide and the low or no costs they have (Ewel et al., 1999). Other introduced species provide few or no benefits (Shackleton et al., 2007; van Wilgen and Richardson, 2014) and are environmentally inconsequential - e.g. insects that are transported by boats between continents and which do not survive in the introduced area.

However, a small proportion of all alien species become invasive (i.e. reproduce and spread over substantial distances from introduction sites; Blackburn et al., 2011). Such growth and spread sometimes results in negative impacts, but even if there is no spread, alien species can be "undesirable" (Fig. 1). Impacts caused by invasive species (and occasionally alien species which are not invasive) include changes to ecosystem services (such as water or grazing supply), changes to ecosystem processes (such as fire and nutrient cycling), reductions in biodiversity, and negative effects on local economies and livelihoods (Levine et al., 2003; Le Maitre et al., 2011; Jeschke et al., 2014; Shackleton et al., 2014). For example, the perennial herb Chromolaena odorata in South Africa prevents the establishment of native plants, reduces grazing ground for native animals, alters natural ecosystem processes, alters features of fire regimes, causes negative impacts on forestry and crop plantations, reduces pasture carrying capacities, and is toxic to humans and animals (Goodall and Erasmus, 1996; te Beest et al., 2015). In New Zealand, the black rat (Rattus rattus) causes substantial declines in native plant and animal populations (Caut et al., 2008), damages agricultural crops and carries human-threatening diseases (Russell et al., 2008). Effective management of such undesirable species often requires the engagement of all stakeholders, to ensure that all relevant ecological and socioeconomic dimensions influencing the management are addressed (Liu and Cook, 2016). A management strategy designed and implemented without engaging all stakeholders can be controversial and might be challenged, ultimately reducing the efficiency of management efforts (Crowley et al., 2017a). For example, an aerial spraying program aimed at eradicating the light brown apple moth (Epiphyas postvittana), a major threat to agriculture in northern California, was challenged by a popular opposition movement which was concerned that the spray might pose a risk to human health (Lindeman, 2013). In this case, the strategy adopted for the management of the alien species created a conflict.

Some alien species, in addition to incurring costs, provide benefits and are, therefore, embraced by certain stakeholders (e.g. Dickie et al., 2014; Kull et al., 2011; Novoa et al., 2015a; Shackleton et al., 2007, 2014; van Wilgen and Richardson, 2012). Alien species with both benefits and costs ("conflict species", Fig. 1) usually lead to conflicts around both their use and management (Dickie et al., 2014; Novoa et al., 2015b; Shackleton et al., 2014; Stanley and Fowler, 2004; van Wilgen and Richardson, 2012, 2014; Woodford et al., 2016). For example, several tree species in the genera Acacia, Pinus and Prosopis, which are highly invasive in many areas of the world, are extensively used in the forestry industry and for agroforestry and silviculture by farmers and rural communities (Kull et al., 2011; Moran et al., 2000; Shackleton et al., 2014). Furthermore, many alien plant invasions that have arisen from 'escaped' horticultural introductions (e.g. the jacaranda tree Jacaranda mimosifolia in South Africa, the African tulip tree Spathodea campanulata in Fiji and the saltcedar Tamarix ramosissima in the USA), have substantial intrinsic and aesthetic value for some stakeholders (Dehnen-Schmutz and Williamson, 2006; Dickie et al., 2014). Several invasive animals [e.g. the Mediterranean mussel (Mytilus galloprovincialis) in South Africa and feral pigs (Sus scrofa) in the USA] and plants [e.g. prickly pear (Opuntia spp.) in Australia and Spain, guava (Psidium spp.) in Mauritius and brambles (Rubus spp.) in Australia, New Zealand and the USA] are used for food (Cole et al., 2012; Naylor et al., 2001; Novoa et al., 2015a; Robinson et al., 2005; Stanley and Fowler, 2004) and numerous invasive fish species [e.g. the rainbow trout (Oncorhynchus mykiss) in Australia, Europe or South Africa] are popular both for food and for sport fishing (Cambray, 2003).

The categorisation of species as inconsequential, desirable, undesirable, or conflict can also change over time (Shackleton et al., 2007). For example, the following species have all become undesirable over time as they have started to spread and caused negative impacts: (1) inconsequential species [e.g. parthenium (Parthenium hysterophorus) in eastern and southern Africa (McConnachie et al., 2011) and the red imported fire ant (Solenopsis invicta) in the USA (LeBrun et al., 2012)], (2) desirable species [e.g. boneseed (Chrysanthemoides monilifera) in Australia (Downey, 2010) and the erect prickly pear (Opuntia stricta) in South Africa (Foxcroft et al., 2004)], and (3) conflict species [e.g. mesquite (Prosopis spp.) in South Africa (Shackleton et al., 2014) and the silver wattle (Acacia dealbata) in Spain (Lorenzo et al., 2010)]. Similarly, a desirable species might become a conflict species [e.g. the prickly pear (Opuntia ficus-

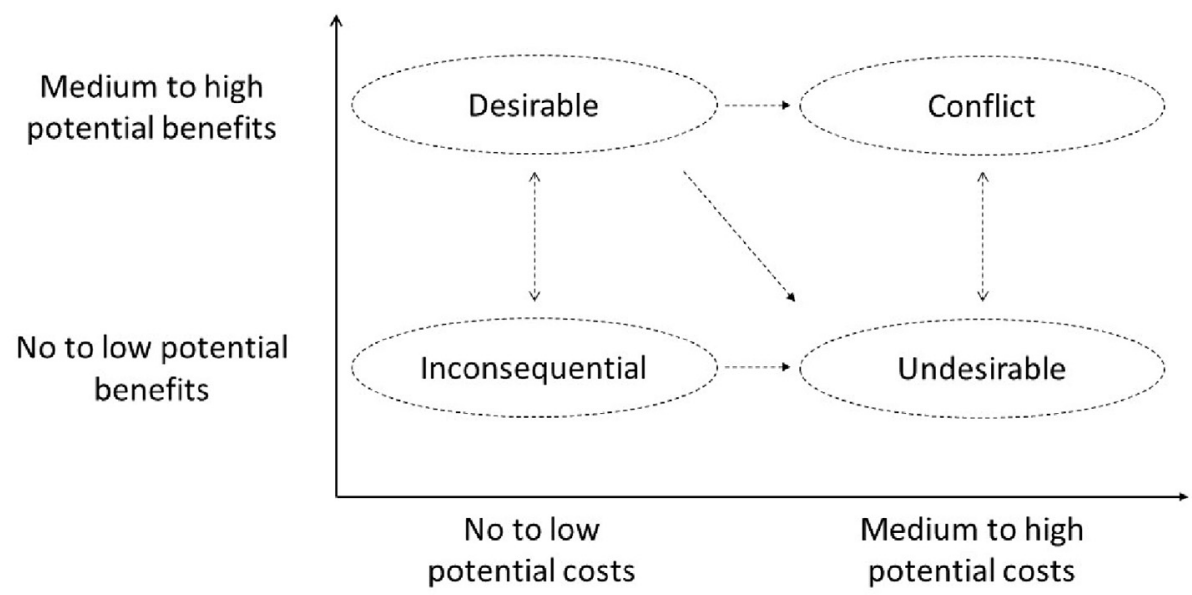

Fig. 1. Classification of alien species based on their potential benefits and costs for society. Arrows indicate potential category changes for a particular species over time. 
indica) in Spain and Turkey (Novoa et al., 2015a) and the Mediterranean mussel (Mytilus galloprovincialis) in South Africa (Branch and Steffani, 2004)].

Achieving workable management strategies for such conflict species depends, to a large extent, on acceptance (if not cooperation and support) from all stakeholders - both those supporting the use of the species, and those supporting its control. A lack of acceptance across stakeholder constituencies often has a negative influence on implementation actions and policy making (FordThompson et al., 2012; Gárcia-Llorente et al., 2008; Reed et al., 2009). For example, in South Africa's Table Mountain National Park, the invasive tree karri gum (Eucalyptus diversicolor) has some negative impacts on water resources. However, it is perceived as beneficial by hikers, cyclists and tree enthusiasts. Due to this conflict of interests, plans to remove the species and restore invaded areas in the National Park were halted (Gaertner et al., 2016). Another example is the blue gum (E. globulus) in Galicia, Spain. Although considered by many stakeholders in the region as one of the most problematic invasive plants, it also has important benefits for the forestry sector (Dehnen-Schmutz et al., 2010; Touza et al., 2014). Consequently, the local government excluded the species from the list of invasive alien plants in the area.

The importance of engaging multiple stakeholder groups in management of alien species (both undesirable and conflict species) has been highlighted before (Kueffer, 2010) and the need for such engagement is stipulated by the Convention on Biological Diversity and in strategies to combat biological invasions in many parts of the world. For example, in 2004, the Invasive Alien Species Strategy for Canada identified a range of stakeholders (including academic researchers, industry, NGOs, and the general public) as "essential players for successfully responding to the challenge of invasive alien species" (Environment Canada, 2004). Similarly, the Guiding Principle 6 (Education and public awareness) of the European Strategy on Invasive Alien Species, includes the need to "work with key stakeholders to produce and disseminate information and guidance on best practices for those using or affected by [invasive alien species]" (Brunel et al., 2013) as a key action. Codes of conduct dealing with the role of horticulture, pet trade, plantation forestry, and zoological gardens and aquaria in disseminating alien species in Europe all stipulate the need for stakeholder engagement (e.g. Brundu and Richardson, 2016 for planted forests). Such engagement is essential for elucidating the factors that shape stakeholders' perceptions and practices i.e. for "framing" the problem (Woodford et al., 2016). It is also essential for identifying valuable local knowledge and practices, promoting awareness and social learning, reaching consensus and gaining support, and formulating co-management programs (Touza et al. 2014; Forsyth et al., 2012; García-Llorente et al., 2008; Moon et al., 2015; Novoa et al., 2015b; Reed, 2008; Reed et al., 2009; Sharp et al., 2011; Stokes et al., 2006). Therefore, the importance of participatory approaches in alien species management has been increasingly recognized (García-Llorente et al., 2008; Shackleton et al., 2015; Crowley et al., 2017b) and the number of studies aiming to understand stakeholders' perceptions to facilitate decision-making in alien species management is growing (e.g. Liu and Cook, 2016; Novoa et al., 2016; Rout et al., 2014). Studies that discuss stakeholder involvement on alien species management are, however, still scarce. To facilitate such work in future, we develop a step-bystep approach to engaging stakeholders in the management of alien species. This approach is based on adaptive management, i.e. a flexible management strategy that can be adjusted as more information (e.g. on stakeholders' perceptions or on outcomes from management actions) becomes available or better understood (Linkov et al., 2006; Williams, 2011).

\section{Methods}

To better understand the issues pertaining to stakeholder engagement in alien species management, we organized a two-day workshop in Cape Town, South Africa, in August 2015. It involved 20 participants working on biological invasions and representing different organizations in South Africa and France (governmental institutions, universities and other scientific institutions). Participants included academics and managers working in different capacities on a variety of invasive organisms and in different areas (urban and rural) and ecosystems (terrestrial and aquatic). South Africa has major problems with biological invasions in freshwater, marine and terrestrial ecosystems and has a long history of scientific study and management of invasions (Richardson et al., 2011). The cross-section of invasive organisms and management issues in the workshop therefore covered many of the most pressing global issues with alien species management.

On the first day of the workshop, participants presented eleven different case studies of conflicts that they had experienced around the management of alien species. Presentations covered: (1) species benefits and costs; (2) affected stakeholders; and ( 3 ) attempts to engage stakeholders (if any) (Table 1). The case studies were chosen with the aim of representing a wide variety of groups-bamboos, cacti, forestry tree species, freshwater species, amphibians, terrestrial invertebrates, and mesquite. This led into various round-table discussions. Based on participants' experiences, and feedback from the group work, we constructed a first draft of a stakeholder-engagement framework for dealing with conflicts in the management of alien species.

On day two of the workshop, participants were separated into break-out groups of 4-6 people and were asked to write down all the steps they found necessary to include in the framework, and the reasons for these. In a following feedback session, participants summarized their discussions. All discussions were videotaped. A revised framework was then developed. The workshop ended with a group discussion and a detailed analysis of each step of the revised framework.

Building on the workshop and incorporating perspectives from elsewhere in the world, this framework was further discussed through additional meetings and e-mail communications involving a collaborative group of researchers interested in the optimum control of invasive species with participants from Australia, La Reunion Island (France) and the United Kingdom. Each step of the framework was further improved by reviewing and drawing on information from various literature sources and by visiting the taped discussions from the workshop.

\section{The framework}

The framework proposed here is designed to be followed by any entity tasked with responding to a concern raised about an alien. The concerns might be raised due to environmental change, the detection of a new incursion, the result of a decision made to address a long-standing issue, or in response to criticism of current or historical control efforts. The overall aim of the framework is to ensure that stakeholders are appropriately considered (and where possible included) in the subsequent decision making process (Fig. 2). The framework consists of 12 steps and 6 decision points. Each of these steps and decision points are discussed below.

\subsection{Step 1. Identify stakeholders}

When there is a need for managing undesirable or conflict species ("target species") - i.e. due to a legislative requirement or to address particular impacts, -it is essential to identify stakeholders 
Table 1

Examples of "conflict species", their costs and benefits, stakeholders' perspectives and outcomes of engagement presented by workshop participants.

\begin{tabular}{|c|c|c|c|c|c|c|c|}
\hline Species group & Benefits & Costs & $\begin{array}{l}\text { Stakeholders opposed to } \\
\text { management }\end{array}$ & $\begin{array}{l}\text { Stakeholders for } \\
\text { management }\end{array}$ & Conflict & $\begin{array}{l}\text { Attempts to engage } \\
\text { stakeholders }\end{array}$ & References \\
\hline $\begin{array}{l}\text { Bamboos } \\
\text { (Bambusoideae) }\end{array}$ & $\begin{array}{l}\text { - Ornamental } \\
\text { - Timber } \\
\text { - Used as food } \\
\text { - Used as fodder } \\
\text { - Carbon sequestration } \\
\text { projects } \\
\text { - Water filtration }\end{array}$ & $\begin{array}{l}\text { - Establish in riparian areas } \\
\text { - Supress regeneration of } \\
\text { surrounding trees }\end{array}$ & $\begin{array}{l}\text { - Commercial cultivators } \\
\text { - Nursery owners }\end{array}$ & $\begin{array}{l}\text { - Commercial growers } \\
\text { - Nursery sellers } \\
\text { - Private landowners }\end{array}$ & $\begin{array}{l}\text { Use and } \\
\text { management }\end{array}$ & Mostly successful & Canavan et al., 2017 \\
\hline Cacti (Cactaceae) & $\begin{array}{l}\text { - Aesthetic value } \\
\text { - Used as food } \\
\text { - Used as fodder } \\
\text { - Used as fences } \\
\text { - Biofuel }\end{array}$ & $\begin{array}{l}\text { - Cause injuries to humans, } \\
\text { wild animals and } \\
\text { livestock } \\
\text { - Reduce grazing potential } \\
\text { - Prevent access to land } \\
\text { - Displace native } \\
\text { biodiversity n }\end{array}$ & $\begin{array}{l}\text { - Nursery owners } \\
\text { - Farmers } \\
\text { - Food scientists } \\
\text { - General public }\end{array}$ & $\begin{array}{l}\text { - Farmers } \\
\text { - Game reserve owners } \\
\text { - Land-managers } \\
\text { - General public }\end{array}$ & $\begin{array}{l}\text { Use and } \\
\text { management }\end{array}$ & Successful & Novoa et al., 2016 \\
\hline $\begin{array}{l}\text { Commercial } \\
\text { forestry trees } \\
\text { species }\end{array}$ & $\begin{array}{l}\text { - Timber } \\
\text { - Pulp } \\
\text { - Employment } \\
\text { opportunities }\end{array}$ & $\begin{array}{l}\text { - Widespread invasions of } \\
\text { adjoining land (often } \\
\text { watersheds) leading to } \\
\text { substantial reductions in } \\
\text { streamflow } \\
\text { - Biodiversity losses }\end{array}$ & $\begin{array}{l}\text { - Commercial } \\
\text { companies }\end{array}$ & $\begin{array}{l}\text { - Conservation agencies } \\
\text { - Landowners } \\
\text { - General public }\end{array}$ & $\begin{array}{l}\text { Use and } \\
\text { management }\end{array}$ & $\begin{array}{l}\text { Largely unsuccessful } \\
\text { (failure to agree on } \\
\text { ownership of the problem } \\
\text { and management options) }\end{array}$ & $\begin{array}{l}\text { van Wilgen and } \\
\text { Richardson, 2012, } \\
\text { 2014; } \\
\text { McConnachie et al., } \\
\text { 2015, } 2016\end{array}$ \\
\hline Freshwater species & $\begin{array}{l}\text { - Recreational/fishing } \\
\text { tournaments, } \\
\text { - Major income for fishing/ } \\
\text { boat shops } \\
\text { - Used as food } \\
\text { - Aesthetic value/pets } \\
\text { - Cultural }\end{array}$ & $\begin{array}{l}\text { - Threat aquatic } \\
\text { biodiversity (through } \\
\text { predation, competition, } \\
\text { habitat alteration, } \\
\text { disease transfer and } \\
\text { hybridization) }\end{array}$ & $\begin{array}{l}\text { - Angling clubs } \\
\text { - Fishermen } \\
\text { - Inland fisheries societies } \\
\text { - Aquaculture sector }\end{array}$ & $\begin{array}{l}\text { - Managers } \\
\text { - Conservation agencies }\end{array}$ & $\begin{array}{l}\text { Use and } \\
\text { management }\end{array}$ & $\begin{array}{l}\text { Largely unsuccessful for } \\
\text { some species, such as } \\
\text { rainbow trout (failure to } \\
\text { agree on the areas to be } \\
\text { managed). Largely } \\
\text { successful for other species, } \\
\text { such as bass. }\end{array}$ & $\begin{array}{l}\text { Hargrove et al., } \\
\text { 2015; Taylor et al., } \\
\text { 2015; Weyl et al., } \\
2015\end{array}$ \\
\hline Amphibians & $\begin{array}{l}\text { - Aesthetic value } \\
\text { - Natural pest control }\end{array}$ & $\begin{array}{l}\text { - Very noisy calls } \\
\text { - Parasite and pathogen } \\
\text { transfer } \\
\text { - Predation } \\
\text { - Toxicity to predators } \\
\text { - Damage infrastructure }\end{array}$ & $\begin{array}{l}\text { - Collectors } \\
\text { - Animal rights activists }\end{array}$ & $\begin{array}{l}\text { - Collectors } \\
\text { - Conservation agencies }\end{array}$ & $\begin{array}{l}\text { Management } \\
\text { actions }\end{array}$ & $\begin{array}{l}\text { Some success, but some } \\
\text { private properties not } \\
\text { accessible to management/ } \\
\text { conservation staff }\end{array}$ & $\begin{array}{l}\text { Measey et al., 2014, } \\
\text { 2015, 2016, 2017; } \\
\text { Vimercati et al., } \\
2017\end{array}$ \\
\hline $\begin{array}{l}\text { Mesquite (Prosopis } \\
\text { spp.) }\end{array}$ & $\begin{array}{l}\text { - Fodder } \\
\text { - Fuelwood } \\
\text { - Honey } \\
\text { - Shade } \\
\text { - Aesthetic value }\end{array}$ & $\begin{array}{l}\text { - Negative health effects to } \\
\text { humans and livestock } \\
\text { - Loss of grazing areas } \\
\text { - Breakage } \\
\text { infrastructure } \\
\text { - Biodiversity impacts } \\
\text { - Economic losses } \\
\text { - Encroachment } \\
\text { - Loss of land }\end{array}$ & $\begin{array}{l}\text { - Some farmers and } \\
\text { community members }\end{array}$ & $\begin{array}{l}\text { - Some farmers and } \\
\text { community members } \\
\text { - Managers } \\
\text { - Conservationists }\end{array}$ & $\begin{array}{l}\text { Use and } \\
\text { management } \\
\text { Management } \\
\text { actions }\end{array}$ & Successful & $\begin{array}{l}\text { Shackleton et al., } \\
\text { 2014, 2015, } 2017\end{array}$ \\
\hline $\begin{array}{l}\text { Terrestrial } \\
\quad \text { invertebrates }\end{array}$ & $\begin{array}{l}\text { - >20 uses were recently } \\
\text { identified, e.g., } \\
\text { biocontrol, silk } \\
\text { production, human food, } \\
\text { animal feed, pets, } \\
\text { pollination, waste } \\
\text { processing or bait for } \\
\text { fishing }\end{array}$ & $\begin{array}{l}\text { - Large damage to native } \\
\text { environments. Most } \\
\text { impacts and risks have } \\
\text { however not been } \\
\text { studied. }\end{array}$ & $\begin{array}{l}\text { - Not studied, but dependant } \\
\text { on use. Probably pet holders, } \\
\text { animal farmers, etc. }\end{array}$ & $\begin{array}{l}\text { - Not studied, but likely } \\
\text { conservationists, }\end{array}$ & Not studied & Not known & $\begin{array}{l}\text { Kumschick et al., } \\
2016\end{array}$ \\
\hline
\end{tabular}




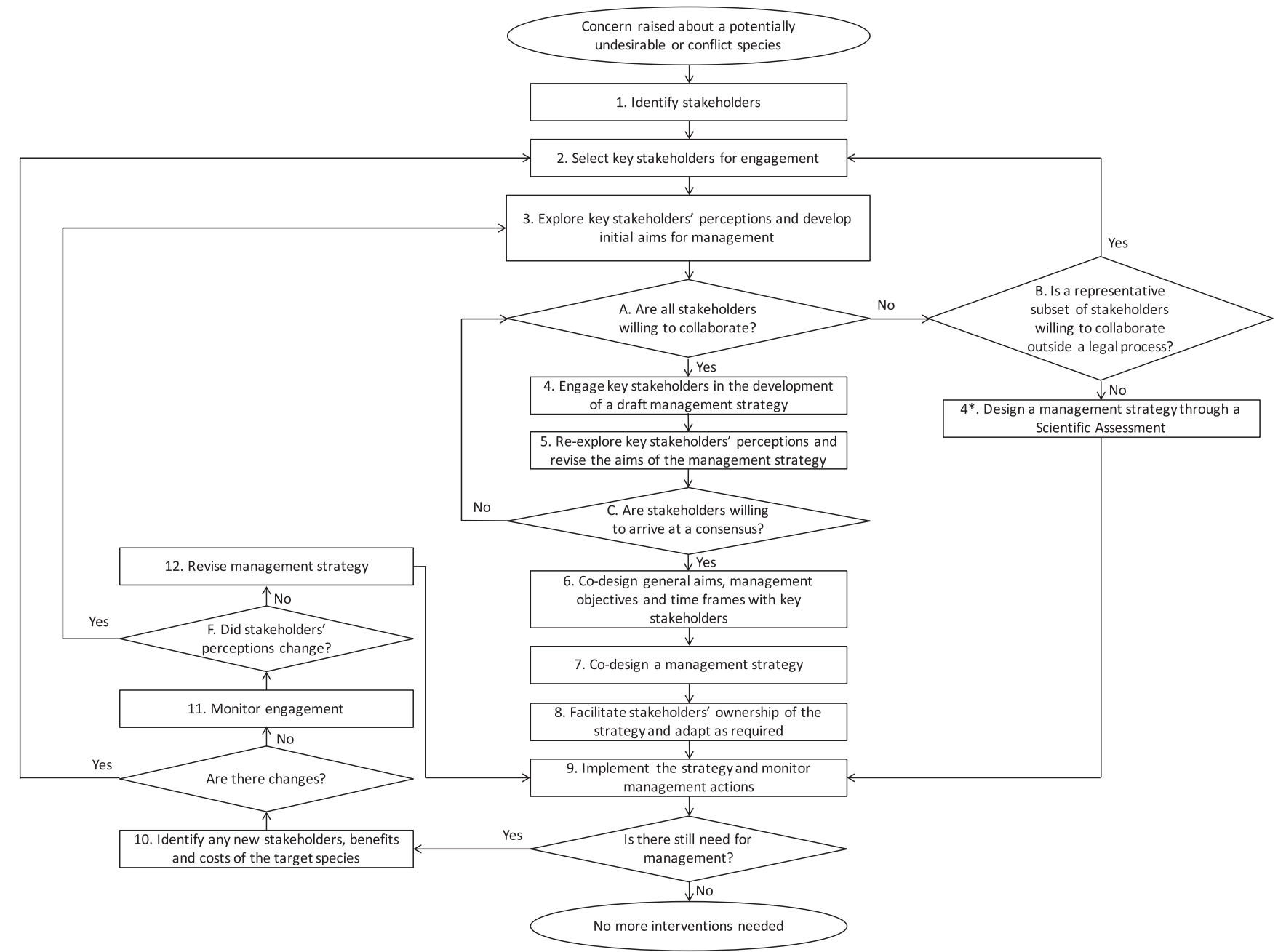

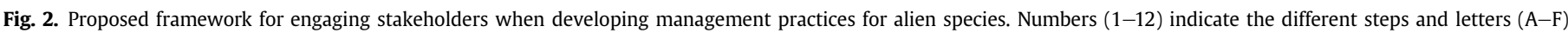
indicate decision points.

that might play a role during the course of the management initiative (Reed et al., 2009). The identification of stakeholders at this stage should aim to be as broad and inclusive as possible, and should consider groups and individuals that might either benefit or experience negative impacts from the target species, as well as those that might experience impacts or risks associated with the actual management intervention.

Many techniques are available for identifying stakeholders. These include network analyses (Scott, 2012) and historical, demographic and geographic techniques (e.g. Babiuch and Farhar, 1994). However, the most popular is the snowball technique (Biernacki and Waldorf, 1981), which involves identifying a small initial pool of stakeholders - through peer recommendation or literature review (including books, scientific articles, newspaper articles, social media or meeting minutes) - and asking them to nominate other stakeholders until no new ones are identified (e.g. Bardsley and Edward-Jones, 2007; Kumschick et al., 2012; Urgenson et al., 2013). For example, Urgenson et al. (2013) aimed to understand the perceptions of stakeholders regarding the control of invasive alien plants on private land in South Africa's Western Cape province. Although they could identify affected landowners through a land management agency, they effectively used the snowball technique to find conservation professionals involved in the management of the target species.
Each target species or group of species will require the engagement of different stakeholders and, depending on the species, most stakeholder groups are often obvious. Table 2 shows some examples of different stakeholder groups that can be expected to be involved in the management of different groups of alien species.

\subsection{Step 2. Select key stakeholders for engagement}

Although all identified stakeholders should ideally be engaged in the management, sometimes this might be impractical (e.g. due to lack of funding, capacity, or time). In such cases, all stakeholders should be categorized, and only those that are most likely to affect the functioning of the management strategy should be engaged (Grimble and Wellard, 1997).

Various approaches have been used to categorize and identify key stakeholders for engagement (Babiuch and Farhar, 1994; Reed and Curzon, 2015). The most widely used is the impact-influence matrix, which categorizes stakeholders according to their influence in the management actions and the impact of the management on them (e.g. Liu and Cook, 2016; Newcombe, 2003; Olander and Landin, 2005; Reed and Curzon, 2015; Walker et al., 2008). This approach, often referred to as stakeholder mapping (Reed et al., 2009), contemplates four stakeholder categories: "Key players", 
Table 2

Example of stakeholders that are expected to have influence on or be affected by the management of different groups of alien species. $\mathrm{x}$ is afected; - is not affected.

\begin{tabular}{|c|c|c|c|c|c|c|}
\hline & Plants & Freshwater species & Marine species & Vertebrates & Terrestrial invertebrates & Amphibians \\
\hline Academics & $\mathrm{x}$ & $\mathrm{x}$ & $\mathrm{x}$ & $\mathrm{x}$ & $\mathrm{x}$ & $\mathrm{x}$ \\
\hline Agricultural sector & $\mathrm{x}$ & - & - & $\mathrm{x}$ & $\mathrm{x}$ & $\mathrm{x}$ \\
\hline Aquaculture sector & - & $\mathrm{x}$ & $\mathrm{x}$ & - & - & $\mathrm{x}$ \\
\hline Collectors & $\mathrm{x}$ & $\mathrm{x}$ & $\mathrm{x}$ & $\mathrm{x}$ & $\mathrm{x}$ & $\mathrm{x}$ \\
\hline Fishermen & - & $\mathrm{x}$ & $\mathrm{x}$ & - & - & - \\
\hline Food industry & $\mathrm{x}$ & $\mathrm{x}$ & $\mathrm{x}$ & $\mathrm{x}$ & $\mathrm{x}$ & $\mathrm{x}$ \\
\hline Forestry sector & $\mathrm{x}$ & - & - & - & $\mathrm{x}$ & - \\
\hline General public & $\mathrm{x}$ & $\mathrm{x}$ & $\mathrm{x}$ & $\mathrm{x}$ & $\mathrm{x}$ & $\mathrm{x}$ \\
\hline Land owners & $\mathrm{x}$ & $\mathrm{x}$ & - & $\mathrm{x}$ & $\mathrm{x}$ & $\mathrm{x}$ \\
\hline Landscapers & $\mathrm{x}$ & - & - & - & - & - \\
\hline Managers \& policy makers & $\mathrm{x}$ & $\mathrm{x}$ & $\mathrm{x}$ & $\mathrm{x}$ & $\mathrm{x}$ & $\mathrm{x}$ \\
\hline NGOs & $\mathrm{x}$ & $\mathrm{x}$ & $\mathrm{x}$ & $\mathrm{x}$ & $\mathrm{x}$ & $\mathrm{x}$ \\
\hline Nursery owners and plant wholesalers & $\mathrm{x}$ & - & - & - & $\mathrm{x}$ & - \\
\hline Pet shop owners & - & $\mathrm{x}$ & $\mathrm{x}$ & $\mathrm{x}$ & $\mathrm{x}$ & $\mathrm{x}$ \\
\hline Recreational ocean users & - & - & $\mathrm{x}$ & - & - & - \\
\hline State agencies & $\mathrm{x}$ & $\mathrm{x}$ & $\mathrm{x}$ & $\mathrm{x}$ & $\mathrm{x}$ & $\mathrm{x}$ \\
\hline
\end{tabular}

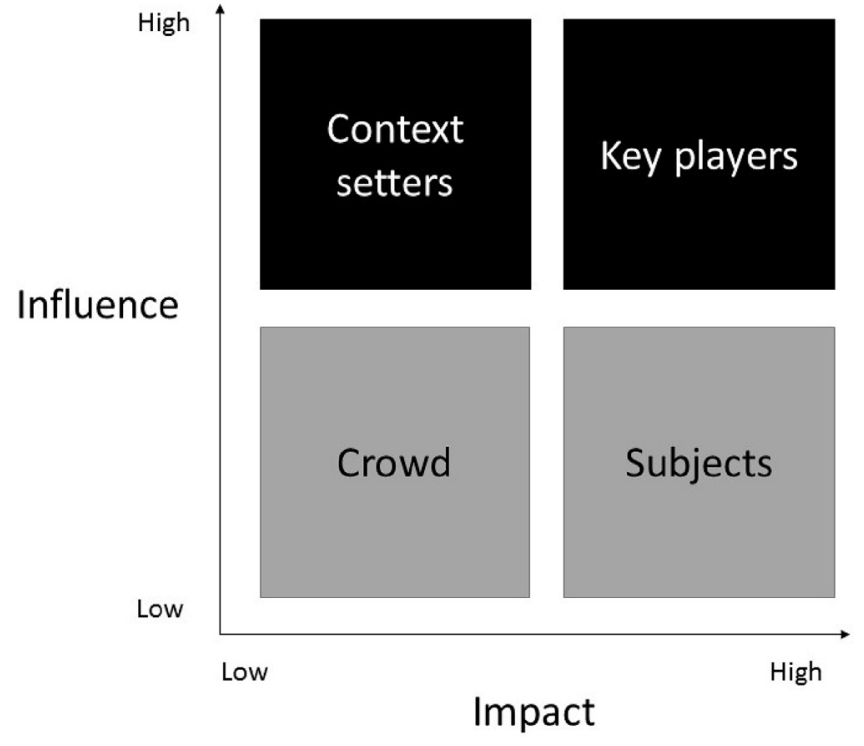

Fig. 3. Impact-influence matrix categorizing stakeholders affected by species into four groups.

with high influence on the management actions and that are highly impacted by the management; "Context setters", with high influence, but are not impacted much; "Subjects", who are highly impacted by the management actions, but have little or no influence over the actions; and the "Crowd", who have little influence and are not heavily impacted by the management (Fig. 3).

When developing management actions, it is tempting to only focus on stakeholders with high influence (key players and context setters), as they will have the highest impact on management decision outcomes (Liu and Cook, 2016; Newcombe, 2003; Olander and Landin, 2005; Reed and Curzon, 2015). For example, in South Africa's Table Mountain National Park, a population of invasive Himalayan tahrs (Hemitragus jemlahicus) was targeted for eradication. There was strong resistance from some members of the public to controlling these mammals (Gaertner et al., 2016), but gaining backing from some influential NGOs and conservation authorities was enough to solve the conflict. The challenge, however, is to also empower those that are most affected by the decisions (the subjects), and some case studies have shown that mobilising stakeholders with low influence can be an effective way of building mass support for management initiatives. For example, a large- scale eradication programme of the invasive American mink (Neovison vison) in north-eastern Scotland was possible due to the engagement of not only scientists, government agencies and national park authorities, but also local fisheries boards and local communities (Bryce et al., 2011). Likewise, in South Africa, engaging the public on the management of bass (Micropterus dolomieu) resulted in the bass angling fraternity providing full support for extirpation actions within selected sites of high conservation value (Weyl et al., 2014).

\subsection{Step 3. Explore key stakeholders' perceptions and develop initial aims for management}

By studying stakeholder perceptions and levels of awareness of the invasions, factors influencing management can be uncovered and explored (Eisweth et al., 2011; García-Llorente et al., 2008; Shackleton and Shackleton, 2016). Moreover, people's views on alien species can be better understood (Urgenson et al., 2013) and their wants and needs for management gauged (Kreuter et al., 2005; Shackleton et al., 2015). Finally, the level of cohesion and consensus between stakeholders can be identified (Fischer et al., 2014; Novoa et al., 2015a,b). Fischer et al. (2014) highlight that understanding stakeholders' beliefs (i.e. their subjective knowledge) about a particular species provides a good basis for gauging possible attitudes towards different management strategies. Therefore, having a broad overview of key stakeholders' beliefs and attitudes towards management of target alien species can help managers develop a shared aim for the management strategy and design a successful engagement process. A variety of techniques can be used to study stakeholders' perceptions, including questionnaires, phone calls, e-mails, site visits and workshops (Reed et al., 2009; Malatinszky, 2016). Using face-to-face interviews, Schüttler and colleagues (2011) explored the perceptions of stakeholders (Chilean Navy members, indigenous Yaghan people, fishermen, public service employees, civilian residents and nature conservationists) regarding two invasive species, the American mink (Neovison vison) and the North American beaver (Castor canadensis), for which management plans, including comanagement, needed to be developed in Chile. Although stakeholders had positive attitudes regarding the control of the invaders, there was disagreement about the goal of the management actions (control or eradication) and the appropriate management method (killing or castration). This suggests that, although the engagement of identified stakeholders and the aim of controlling both invaders were achievable, during the engagement process, information about the feasible control methods and their trade-offs should be 
provided. In this case, discussion of the option of establishing a nocontrol area for $C$. canadensis might have been helpful.

\subsection{Decisions A-B. Are all selected stakeholders willing to collaborate?}

Once the perceptions of all selected stakeholders are known, we can proceed to engagement (Step 4). However, the results of Step 3 might show that some stakeholder groups are not interested in participating further in the process, or are against any form of management. In such situations, a smaller group of stakeholders may be selected (Step 2). Alternatively, if the selected stakeholders do not agree, it can be essential to have a formal process, e.g. a scientific assessment (Step 4*; Scholes et al., 2017).

\subsection{Step 4. Engage key stakeholders in the development of a draft management strategy}

Engaging stakeholders is one of the most important steps of the proposed framework. A key aim of engagement is to increase levels of trust and establish collaborations among stakeholders, promote social learning and information sharing. Moreover, solving the potential differences between stakeholder groups is crucial. Engagement can be achieved by promoting dialogue among stakeholders through an open and fair participation process through workshops or social media, such as blogs or Facebook pages, where stakeholders can share their perceptions (e.g. Estévez et al., 2015; Ford-Thompson et al., 2012). For example, Novoa et al. (2016) organized a workshop with stakeholders who either benefit from or suffer the costs of invasive cacti in South Africa. Before the workshop, some stakeholders were not fully aware of the benefits and negative impacts of cacti in South Africa. In the workshop, stakeholders listened to each others' perceptions, wants and needs. The workshop was shown to increase different stakeholders' knowledge and understanding of the species' benefits and adverse impacts, and improved their acceptance and willingness to collaborate on the proposed management actions.

If the strategy aims to provide the basis for managing alien species across different regions (with different climates, land uses, economies or demographics), a different engagement process might need to be carried out in each region. For example, Friedel et al. (2011) aimed to engage governmental and nongovernmental organizations on the management of buffel grass (Cenchrus ciliaris) in Australia. They ran workshops in four regions, each of them having a different climate, land use and pastoral dependence on buffel grass. Overall, they found regional differences in stakeholders' perceptions of the benefits and costs of buffel grass and identified a need for different management objectives in the different regions.

A key requirement of the engagement process is having a facilitator to lead the process and balance any competing interests of stakeholders. Such a facilitator or mediator should ideally be a neutral third party with expertise in conflict resolution, and should assist stakeholders to voluntarily reach consensus on the approaches to be adopted for managing the target species (Lampe, 2001).

\subsection{Step $4^{*}$. Design a management strategy through a scientific assessment}

When achieving acceptance from all stakeholders is not possible, a formal scientific assessment process can be set up. Such a scientific assessment is an evaluation of information, done by experts on the field, aiming to guide decision-makers on the management of the target species (Scholes et al., 2017).
Management then proceeds (Step 9), with decisions ultimately enforced through legislation (van Wilgen and Richardson, 2012). However, this approach might create conflicts, since stakeholders might feel excluded from the management process and seek alternative ways of achieving their goals (Crowley et al., 2017a,b). For example, on Lord Howe Island (Australia), members of the public opposed a program to eradicate rodents from the island because they felt excluded from the design of the management strategy (Lord Howe Island Community Liaison Group, 2013).

\subsection{Step 5. Re-explore key stakeholders' perceptions and revise the aims of the management strategy}

After the engagement process, it is important to re-assess the perception of stakeholders to determine whether the engagement process has built cohesion and trust, or if further engagement is needed. The techniques available for exploring whether stakeholders' perceptions and attitudes towards the target species have changed are those described in Step 3. However, in the current step (5), additional efforts should be targeted to explore stakeholders' attitudes towards the other stakeholders. This should be done with the help of the facilitator or mediator mentioned in Step 4 and through open and individual dialogue between each stakeholder and the facilitator.

\subsection{Decision C. Are stakeholders willing to arrive at a consensus?}

In some cases, consensus is easily reached. For example, Novoa et al. (2016) showed, through the results of questionnaires, that only one session of interaction and dialogue between stakeholders affected by cactus invasions was enough to improve their willingness to collaborate on cactus management actions. This shows how engagement and information exchange can change stakeholders' beliefs (subjective knowledge) about a target species and subsequently change their attitudes towards management interventions.

However, sometimes, multiple engagements are needed before stakeholders are prepared to arrive at a consensus in the management process. For example, in the Cape Floristic Region (South Africa), several meetings had to be organized to engage the public (especially anglers, the main stakeholder group responsible for the introduction of freshwater fishes) on the extirpation of non-native fish from priority rivers. However, opposition to the project still remains. Conservation managers, through a Freshwater Angling Forum, are still working closely with local angling groups to achieve engagement (Marr et al., 2012).

Unfortunately, in certain situations it might not be possible to achieve consensus. For example, in Cape Town (South Africa), European mallards (Anas platyrhynchos) were targeted for eradication, as they interbreed with indigenous yellow-billed ducks (Anas undulata). However, efforts to engage the public were not successful, because arguments to control the European mallards failed to convince the opposing stakeholders (Gaertner et al., 2016). The presence of powerful stakeholders in each of these cases has hindered the engagement process and progress towards management implementation (Fig. 3). In such cases, the management strategy might need to be designed through a scientific assessment (Step $4^{*}$ ), and the management goals might need to be adapted to accommodate partial or complete tolerance of the target species i.e. little management targeting the species could be designed and implemented. For example, in South Africa, the invasive river red gum (Eucalyptus camaldulensis) is an attractive ornamental tree. In the case of public social opposition and lack of willingness to arrive to a consensus regarding the clearing of river red gums, an appropriate management goal would be to tolerate large individuals in public parks and gardens, but to remove plants from 
protected areas and river courses (Gaertner et al., 2016; Mangachena and Geerts, 2017).

\subsection{Step. 6. Co-design general aim, management objectives and time frames with key stakeholders}

Once consensus among key stakeholders is achieved, the aim of the management strategy must be revised, in order to incorporate stakeholders' wants and needs. Workshops in which team decisionmaking techniques are applied can be used to translate stakeholders' knowledge and needs into alien species management objectives that are broadly supported by all stakeholders. For example, Novoa et al. (2016) organized a workshop at which biological control researchers, farmers, food scientists, fruit pickers, game reserve owners, invasion biologists, invasive species managers, land managers and nursery owners co-designed aims and objectives for a national strategy for managing cactus species in South Africa (Kaplan et al., 2017). Similarly, Shackleton and Shackleton (2016) held several workshops with academics, farmers and managers during which, in order to improve management interventions, they identified barriers and potential solutions (adaptation responses) for the management of invasive mesquite (Prosopis species) in South Africa.

There are many techniques than can be used in such workshops. For example, the Round Robin Brainstorming Technique (RRBT) involves giving each stakeholder a fixed number of sheets of paper and asking them to write one management recommendation on each paper (Brilhart and Jochem, 1964). Stakeholders are then asked to present (one at a time) their written recommendations to the full group. Another example is the Charette Procedure (CP), which is especially useful when many stakeholders are involved (Manktelow, 2009). It involves separating stakeholders into several small groups, preferably mixing stakeholder types (e.g. as categorized in Fig. 3). Stakeholders then brainstorm and discuss potential management recommendations until consensus is reached within the group. A representative of each group then presents their recommendations to all stakeholders. Although the RRBT and CP techniques are generally successful (e.g. Novoa et al., 2016), some stakeholders may find it difficult to share their knowledge and opinions openly. In these situations, the use of a Metaplan (Ramshaw, 1989) would be recommended. This technique is similar to the RRBT, but once the recommendations are written, each stakeholder anonymously places his or her papers on the wall. A potential difficulty of all these techniques is to separate personal views of people involved in the engagement process from those of the organizations, constituencies or stakeholder groups they represent. Moreover, discussing management recommendations under high levels of uncertainty (such as unknown effectiveness of control actions) can be difficult. Under such conditions, scenario planning is an effective approach to guide the co-design of management objectives (Peterson et al., 2003). For example, RouraPascual and colleagues (2010) used scenario planning for guiding the management of invasive plants in the Cape Floristic Region (South Africa) under several uncertainties (e.g. "how is funding going to change?" or "is the institutional capacity going to increase or decrease?").

Once all recommendations are presented (independently of the technique used), they should be discussed until every stakeholder agrees to a final set of management objectives. To achieve consensus and avoid conflicts, once again the facilitator of these discussions should be neutral (Deelstra et al., 2003; Kaner, 2014) and capable of mitigating tensions (Morris and Baddache, 2012), since certain topics can be controversial or provocative, creating unexpected dynamics or rivalries between stakeholders. Finally, all management objectives should be documented in writing, and the facilitator should agree with stakeholders on their time frames and when they will be updated (Morris and Baddache, 2012).

\subsection{Step 7. Co-design a management strategy}

The final set of management objectives documented in Step 6 must be incorporated into an effective management strategy. Such a strategy can be drafted by a core group of scientific and/or management experts, and it should clearly state the management objectives, facilitate the implementation of all available management practices needed to achieve those objectives, and define clear areas of responsibility for implementation at all levels (national, provincial or municipal) (e.g. Kaplan et al., 2017; van Leeuwen et al., 2014; van Wilgen et al., 2011). This means that the strategy should clearly state what is going to be done and when, who is going to do it, how it will be paid for, and how the success of its implementation will be determined (Wilson et al., 2017). Moreover, the management strategy should include a communication plan that will help to target the audience with identified communication tools. Finally, all the process of designing the management strategy should be transparent and accessible to all stakeholders (Malatinszky et al., 2013).

\subsection{Step 8. Facilitate stakeholders' ownership of the strategy and adapt as required}

After producing a management strategy, it is important to present it to all stakeholders, so they can validate the information collectively. This will inform stakeholders how their feedback has been used, help mitigate misunderstandings, and build coownership and mutual trust. Moreover, this process can help eliminate linguistic uncertainties, so that stakeholders share a common understanding of each action (Liu and Cook, 2016).

For example, Novoa et al. (2015b) organized a workshop in which they followed a consultative process with stakeholders to design a list of potentially invasive cactus species whose introduction and use should be prohibited in South Africa. After the workshop, the list was compiled by researchers and then presented to all stakeholders for validation and adaptation. The resulting list was adopted in the final version of the National Environmental Management: Biodiversity Act, Alien and Invasive Species regulations that came into force in October 2014. This process encouraged stakeholder ownership and ensured the buy-in of all stakeholders into the national regulations. Being able to demonstrate that participants can potentially influence decisions will likely increase willingness to be engaged in the process in future.

\subsection{Step 9. Implement the strategy and monitor management actions}

Once a management strategy is accepted and published, it can be implemented (e.g. Borja et al., 2010; van Leeuwen et al., 2014; Vreysen et al., 2007). Essentially, coordinated and collaborative partnerships with capacity and funding are almost always necessary to successfully implement a management strategy. Moreover, there must be the involvement of a champion to ensure that, when underway, management is implemented and the objectives and time frames are met (Wilson et al., 2017).

If the management strategy was co-designed and accepted by all key stakeholders, conflicts around the implementation should be minimal. However, during implementation, other stakeholders with views against management actions might materialise. As such, if the management strategy was co-designed with stakeholders or if it was designed through a scientific assessment, providing sufficient information during management interventions (e.g. 
explanatory billboards in the managed area, websites or Facebook pages) might help to reduce conflict with potential stakeholders previously not involved in the engagement process. Therefore, this step must include ongoing communication between different parties to make sure that, as much as possible, all stakeholders are informed about actions taken, so that their trust is maintained.

The effectiveness of the management actions needs to be measured at appropriate intervals. Monitoring should be established based on a set of target actions with related indicators of success/progress associated to the main objectives stated in the management strategy (Shackleton et al., 2017). However, limited resources can make it difficult to effectively monitor management actions across large areas (Crall et al., 2010). In such cases, this process can be facilitated by engaging different stakeholders (e.g. through citizen science initiatives), making it time and cost effective. Involving stakeholders through citizen science for monitoring and surveying alien species has been used in numerous instances and shown to encourage participation and ownership (Delaney et al., 2008). For example, in Texas, citizen scientists are trained to detect the dispersal of invasive species and report them into an online mapping database. This program, known as "Invaders of Texas" is focused on long-term surveying and monitoring of invasive species (Gallo and Waitt, 2011). Another example is "Invasoras.pt", a Portuguese program that engages the general public to support the management of invasive species. One of its core elements is a WebMapping platform that intends to engage volunteers to geolocate invasive plants in Portugal (Marchante et al., 2016). A similar web-based platform encourages citizens in different regions of Canada and the United States to use their smartphones to report invasive species sightings (eddmaps.org).

\subsection{Decision D. Is there still need for management?}

If monitoring results indicate that there is no longer need for management, no further interventions are needed. However, if only a subset of the management objectives has been achieved, if unanticipated conflicts occur during implementation, or if new management objectives have to be designed, further steps need to be followed (i.e. proceed to step 10).

\subsection{Step 10. Identify any new stakeholders, benefits, and costs}

During the implementation of the management strategy, new stakeholders, new benefits and new costs of the target species and its management might arise. Some key stakeholders, particularly among the general public, only emerge after the management intervention is implemented. These are often highly motivated and influential stakeholders that can help or hinder management programmes. Examples of newly emerging stakeholders are residents in areas that are treated for invasive plants removal, who are fearful of being affected by chemical spraying (e.g. Myers et al., 2000).

\subsection{Decision E. Are there changes?}

If any changes are detected, a new engagement process (Step 2) should be initiated. In case no changes are detected, step 11 should be followed.

\subsection{Step 11. Monitor stakeholders' perceptions}

During implementation, stakeholders might lose or gain interest in the management strategy - e.g. satisfaction with the participatory process may be affected by management outcomes (McKinney and Field, 2008). In this case, stakeholder perceptions need to be reassessed following the same approach as in Steps 3 and 7.

\subsection{Decision F. Did stakeholders' perceptions change?}

If the assessment reveals that stakeholders' perceptions changed during implementation, it is important to understand why (Step 3). However, if stakeholders' perceptions did not change, one can proceed to step 12, in order to revise the management strategy adopted.

\subsection{Step 12. Revise management strategy}

Before continuing with the implementation of the proposed management strategy, all management objectives, lines of responsibility and time frames should be revised. If all of these are still appropriate, implementation can continue. However, if they are deemed to be no longer adequate, before implementation, they should be adapted with the key stakeholders or the scientific assessment team.

\section{Discussion}

Acceptance of the management of alien species by all stakeholders - from the decision makers that allocate funding for management, to organizations that help implement management actions, to the industries that might lose commercial opportunities, to local people who care - is needed if costly conflicts are to be avoided. However, many stakeholders are often not aware of the suite of impacts caused by alien species and the potential benefits of management, which results in a lack of collaboration and support for management (Courchamp et al., 2017). Moreover, since the management of alien species often involves restrictions on trade, the use of chemicals or biological control agents or the extermination of valued species, management actions are regularly challenged by social conflicts among stakeholders (Crowley et al., 2017a).

Aiming to minimize such conflicts and promote collaboration, we propose a framework based on the principles of stakeholder engagement - i.e. the process by which an organization involves all who may be affected by or can influence the implementation of its decisions in a decision making procedure (Carroll et al., 2016). The framework we propose includes information on the steps that can be followed, and the techniques that can be applied, to engage stakeholders in issues relating to the management of alien species. The proposed framework provides opportunities for collaboration, in order to further align management practices with stakeholders' needs and expectations. Therefore, we believe this framework can help managers and policy makers develop and implement conflictreduced management strategies with the buy-in of stakeholders.

This framework was developed in part on the basis of what has already been done in real-world situations (see for example Novoa et al., 2016 for steps 1, 3, 4, 5, 6 and 7). However, the proposed framework still needs to be implemented in its entirety and tested for its applicability. Nonetheless, we envisage that it will be of great help for practitioners to develop successful alien species management strategies.

When using the proposed framework, some factors need to be taken into account. Firstly, we acknowledge that the management of each alien species or group of alien species involves a unique configuration of stakeholders, context and issues. Therefore, we caution that, in some cases, due to a lack of funding or capacity, or to the presence of unavoidable conflicts, it might not be possible to achieve collaboration among all stakeholders. In such cases, options include proceeding with legal measures to ensure compliance with actions approved by relevant authorities, promoting various levels of tolerance of the target alien species, or setting up a formal scientific assessment process (Scholes et al., 2017). As previously 
mentioned, these approaches might trigger management conflicts, which can drain resources and create distrust (Crowley et al., 2017a). Therefore, they should only be used when engagement is absolutely not possible and they should incorporate deliberative and participatory processes such us structured decision-making or social impact assessment (Crowley et al., 2017b).

Finally, the scale and duration of the engagement process are also influenced by the available resources (both human and monetary). It can be costly to organise several workshops or certain stakeholders might not be able to afford attendance. But we would strongly argue that this process should not be seen as an optional extra. The costs of a conflict arising later in the management process will likely vastly outweigh the costs of considering stakeholders early in the process. Moreover, such conflict can prevent any form of management and hamper any future attempts.

\section{Conclusion}

Conflicts between stakeholders can hamper environmental management actions (Cole, 1993; de Wit et al., 2001; Arlanghaus, 2005). Stakeholder engagement, by considering more comprehensive information inputs (Reed, 2008), is recognized as essential for developing effective, equitable, sustainable and conflict-free environmental management strategies (Grimble and Wellard, 1997; Jolibert and Wesselink, 2012; Colvin et al., 2016). Therefore, by placing stakeholders at the centre of the development and implementation of the decision process dealing with conflicts of interest in alien species, our framework provides a workable and effective approach to reduce the risk of failing to implement alien species management strategies.

\section{Acknowledgements}

We thank Paul Downey for his comments on an early version of the manuscript. This work was supported by the Working for Water (WfW) Programme of the South African Department of Environmental Affairs, through the South African National Biodiversity Institute's Invasive Species Programme (SANBI ISP) and through the DST-NRF Centre of Excellence for Invasion Biology (C•I•B) (as part of the $\mathrm{C} \bullet \mathrm{I} \bullet \mathrm{B} / \mathrm{WfW}$ collaborative research programme on "Research for Integrated Management of Invasive Alien Species"). We acknowledge additional support from the National Research Foundation (grant 85417 to D.M.R. and 87843 to S.G.). AN also acknowledges funding from project no. 14-36079G Centre of Excellence PLADIAS (Czech Science Foundation) and long-term research development project RVO 67985939 (The Czech Academy of Sciences). This work was co-funded by the European Union: Agricultural Fund for Rural Development (EAFRD), by the Conseil Départemental de la Réunion and by the Centre de Coopération Internationale en Recherche Agronomique pour le Dévelopment (CIRAD). We also thank the French Department of Environment, planning and housing for co-funding this research study.

\section{References}

Arlinghaus, R., 2005. A conceptual framework to identify and understand conflicts in recreational fisheries systems, with implications for sustainable management. Aquat. Resour. Cult. Dev. 1, 145-174.

Babiuch, W.M., Farhar, B.C., 1994. Stakeholder Analysis Methodologies Resource Book. National Renewable Energy Lab, United States.

Bardsley, D.K., Edward-Jones, G., 2007. Invasive species policy and climate change: social perceptions of environmental change in the Mediterranean. Environ. Sci. Policy 10, 230-242.

Biernacki, P., Waldorf, D., 1981. Snowball sampling: problems and techniques of chain referral sampling. Sociol. Methods. Res. 10, 141-163.

Blackburn, T.M., Pyšek, P., Bacher, S., Carlton, J.T., Duncan, R.P., Jarošík, V. Wilson, J.R., Richardson, D.M., 2011. A proposed unified framework for biological invasions. Trends Ecol. Evol. 26, 333-339.
Borja, Á., Elliott, M., Carstensen, J., Heiskanen, A.S., van de Bund, W., 2010. Marine management-towards an integrated implementation of the european marine strategy framework and the water framework directives. Mar. Pollut. Bull. 60, 2175-2186.

Branch, G.M., Steffani, C.N., 2004. Can we predict the effects of alien species? A casehistory of the invasion of South Africa by Mytilus galloprovincialis (Lamarck). J. Exp. Mar. Biol. Ecol. 300, 189-215.

Brilhart, J.K., Jochem, L.M., 1964. Effects of different patterns on outcomes of problem-solving discussion. J. Appl. Psychol. 48, 175-179.

Brundu, G., Richardson, D.M., 2016. Planted forests and invasive alien trees in Europe: a Code for managing existing and future plantings to mitigate the risk of negative impacts from invasions. NeoBiota 30, 5-47.

Brunel, S., Fernández-Galiano, E., Genovesi, P., Heywood, V.H., Kueffer, C. Richardson, D.M., 2013. Invasive Alien Species: a Growing but Neglected Threat? in: European Environment Agency, Late Lessons from Early Warning: Science, Precaution, Innovation. Lessons for preventing harm. European Environment Agency Report, Copenhagen, p. 30.

Bryce, R., Oliver, M.K., Davies, L., Gray, H., Urquhart, J., Lambin, X., 2011. Turning back the tide of American mink invasion at an unprecedented scale through community participation and adaptive management. Biol. Conserv. 144, 575-583.

Cambray, J.A., 2003. The global impact of alien trout species - a review: with reference to their impacts in South Africa. Afr. J. Aquat. Sci. 28, 61-67.

Canavan, S., Richardson, D.M., Visser, V., Le Roux, J.J., Vorontsova, M.S., Wilson, J.R., 2017. The global distribution of bamboos: assessing correlates of introduction and invasion. AoB Plants 9, plw078. https://doi.org/10.1093/aobpla/plw078.

Carroll, A.B., Karakowsky, L., Buchholtz, A.K., 2016. Business and Society: Ethics and Stakeholder Management. Cram101 Textbook Reviews.

Caut, S., Angulo, E., Courchamp, F., 2008. Dietary shift of an invasive predator: rats, seabirds and sea turtles. J. Appl. Ecol. 45, 515-523.

Cole, D.N., 1993. Minimazing conflict between recreation and nature conservation. In: Smith, D.S., Hellmund, P.C. (Eds.), Ecology of Greeways: Design and Function of Linear Conservation Areas. Univ. of Minnesota Press, Minneapolis, pp. 105-122.

Cole, R.J., Litton, C.M., Koontz, M.J., Loh, R.K., 2012. Vegetation recovery 16 years after feral pig removal from a wet Hawaiian forest. Biotropica 44, 463-471.

Colvin, R.M., Witt, G.B., Lacey, J., 2016. Approaches to identifying stakeholders in environmental management: insights from practitioners to go beyond the 'usual suspects'. Land Use Pol. 52, 266-276.

Courchamp, F., Fournier, A., Bellard, C., Bertelsmeier, C., Bonnaud, E., Jeschke, J.M., Russell, J.C., 2017. Invasion biology: specific problems and possible solutions. Trends Ecol. Evol. 32, 13-22.

Crall, A.W., Newman, G.J., Jarnevich, C.S., Stohlgren, T.J., Waller, D.M., Graham, J., 2010. Improving and integrating data on invasive species collected by citizen scientists. Biol. Invasions 12, 3419-3428.

Crowley, S.L., Hinchliffe, S., McDonald, R.A., 2017a. Conflict in invasive species management. Front. Ecol. Environ. 15, 133-141.

Crowley, S.L., Hinchliffe, S., McDonald, R.A., 2017b. Invasive species management will benefit from social impact assessment. J. Appl. Ecol. 54, 351-357.

Deelstra, Y., Nooteboom, S.G., Kohlmann, H.R., Van den Berg, J., Innanen, S., 2003. Using knowledge for decision-making purposes in the context of large projects in The Netherlands. Environ. Impact Assess. 23, 517-541.

Dehnen-Schmutz, K., Williamson, M., 2006. Rhododendron ponticum in Britain and Ireland: social, economic and ecological factors in its successful invasion. Environ. Hist. Camb 12, 325-350.

Dehnen-Schmutz, K., Chas-Amil, M.L., Touza, J., 2010. Stakeholders' perceptions of plant invasions in Galicia. Spain. Asp. Appl. Biol. 104, 13-18.

Delaney, D.G., Sperling, C.D., Adams, C.S., Leung, B., 2008. Marine invasive species: validation of citizen science and implication for national monitoring networks. Biol. Invasions 10, 117-128.

Dickie, I.A., Bennett, B.M., Burrows, L.E., Nuñez, M.A., Peltzer, D.A., Porté, A., Richardson, D.M., Rejmánek, M., Rundel, P.W., van Wilgen, B.W., 2014. Conflicting values: ecosystem services and invasive tree management. Biol. Invasions 16, 705-719.

Downey, P.O., 2010. Managing widespread alien plant species to ensure biodiversity conservation: a case study using an 11-step planning process. Invasive Plant Sci. Manag. 3, 451-461.

Eisweth, M.E., Yen, S.T., van Kooten, G.C., 2011. Factors determining awareness and knowledge of aquatic invasive species. Ecol. Econ. 70, 1672-1679.

Environment Canada, 2004. An Invasive Alien Species Strategy for Canada. Government of Canada, Ottawa.

Ewel, J.J., O'Dowd, D.J., Bergelson, J., Daehler, C.C., D'Antonio, C.M., Gómez, L.D., Gordon, D.R., Hobbs, R.J., Holt, A., Hopper, K.R., Hughes, C.E., LaHart, M., Leakey, R.R.B., Lee, W.G., Loope, L.L., Lorence, D.H., Louda, S.M., Lugo, A.E., McEvoy, P.B., Richardson, D.M., Vitousek, P.M., 1999. Deliberate introductions of species: research needs benefits can be reaped, but risks are high. Bioscience 49, 619-630.

Estévez, R.A., Anderson, C.B., Pizarro, J.C., Burgman, M.A., 2015. Clarifying values, risk perceptions, and attitudes to resolve or avoid social conflicts in invasive species management. Cons. Biol. 29, 19-30.

Fischer, A., Selge, S., van der Wal, R., Larson, B.W.H., 2014. The public and professionals reason similarly about the management of non-native invasive species. A quantitative investigation of the relationship between beliefs and attitudes. PLos One. https://doi.org/10.1371/journal.pone.0105495.

Ford-Thompson, A.S.E., Snell, C., Saunders, G., White, P.C.L., 2012. Stakeholder participation in management of invasive vertebrates. Conserv. Biol. 26, 
$345-356$.

Forsyth, G.G., Le Maitre, D.C., O'Farrell, P.J., van Wilgen, B.W., 2012. The prioritization of invasive alien plant control projects using multi-criteria decision model informed by stakeholder input and special data. J. Environ. Manag. 103, 51-57.

Foxcroft, L.C., Rouget, M., Richardson, D.M., MacFadyen, S., 2004. Reconstructing 50 years of Opuntia stricta invasion in the Kruger National Park, South Africa: environmental determinants and propagule pressure. Divers. Distrib. 10, 427-437.

Friedel, M.H., Grice, A.C., Marshall, N.A., Van Klinken, R.D., 2011. Reducing contention amongst organisations dealing with commercially valuable but invasive plants: the case of buffel grass. Environ. Sci. Policy 14, 1205-1218.

Gaertner, M., Larson, B.M., Irlich, U.M., Holmes, P.M., Stafford, L., van Wilgen, B.W., Richardson, D.M., 2016. Managing invasive species in cities: a framework from Cape Town, South Africa? Landsc. Urban Plan 151, 1-9.

Gallo, T., Waitt, D., 2011. Creating a successful citizen science model to detect and report invasive species. Bioscience 61, 459-465.

García-Llorente, M., Martín-López, B., González, J.A., Alcorlo, P., Montes, C., 2008. Social perceptions of the impacts and benefits of invasive alien species: implications for management. Biol. Conserv. 141, 2969-2983.

Goodall, J.M., Erasmus, D.J., 1996. Review of the status and integrated control of the invasive alien weed, Chromolaena odorata, in South Africa. Agric. Ecosyst. Environ. 53, 151-164.

Grimble, R., Wellard, K., 1997. Stakeholder methodologies in natural resource management: a review of principles, contexts, experiences and opportunities. Agric. Syst. 55, 173-193.

Hargrove, J.S., Weyl, O.L., Allen, M.S., Deacon, N.R., 2015. Using tournament angler data to rapidly assess the invasion status of alien sport fishes (Micropterus spp.) in Southern Africa. PLos One. https://doi.org/10.1371/journal.pone.0130056.

Jeschke, J.M., Bacher, S., Blackburn, T.M., Dick, J.T.A., Essl, F., Evans, T., Gaertner, M., Hulme, P.E., Kühn, I., Mrugala, A., Pergl, J., Pyšek, P., Rabitsch, W., Ricciardi, A., Richardson, D.M., Sendek, A., Vilá, M., Winter, M., Kumschick, S., 2014. Defining the impact of non-native species. Conserv. Biol. 28, 1188-1194.

Jolibert, C., Wesselink, A., 2012. Research impacts and impact on research in biodiversity conservation: the influence of stakeholder engagement. Environ. Sci. Policy 22, 100-111.

Kaner, S., 2014. Facilitator's Guide to Participatory Decision-making. Jossey-Bass, San Francisco.

Kaplan, H., Wilson, J.R.U., Klein, H., Henderson, L., Zimmermann, H.G., Manyama, P., Ivey, P., Richardson, D.M., Novoa, A., 2017. A proposed national strategic framework for the management of Cactaceae in South Africa. Bothalia 47, 1-12. https://doi.org/10.4102/abc.v47i2.2149.

Kreuter, U.P., Amestoy, H.E., Kothmannn, M.M., Ueckert, D.N., McGinty, W.A., Cummings, S.R., 2005. The use of brush management methods: a Texas landowner survey. Range. Ecol. Manag. 54, 284-291.

Kueffer, C., 2010. Transdisciplinary research is needed to predict plant invasion in an era of global change. Trends Ecol. Evol. 25, 619-620.

Kull, C.A., Shackleton, C.M., Cunningham, P.J., Ducatillon, C., Dufour-Dror, J., Esler, K.J., Friday, J.B., Gouveia, A.C., Griffin, A.R., Marchante, E., Midgley, S.J., Pauchard, A., Rangan, H., Richardson, D.M., Rinaudo, T., Tassin, J., Urgenson, L.S., von Maltitz, G.P., Zenni, R.D., Zylstra, M.J., 2011. Adoption, use and perception of Australian acacias around the world. Divers. Distrib. 17, 822-836.

Kumschick, S., Bacher, S., Dawson, W., Heikkilä, J., Sendek, A., Pluess, T., Robinson, T., Kühn, I., 2012. A conceptual framework for prioritization of invasive alien species for management according to their impact. NeoBiota 15, 69-100. https://doi.org/10.3897/neobiota.15.3323.

Kumschick, S., Devenish, A., Kenis, M., Rabitsch, W., Richardson, D.M., Wilson, J.R.U., 2016. Intentionally introduced terrestrial invertebrates: patterns, risks, and options for management. Biol. Invasions 18, 1077-1088.

Lampe, M., 2001. Mediation as an ethical adjunct of stakeholder theory. J. Bus. Ethics 31, 165-173.

LeBrun, E.G., Plowes, R.M., Gilbert, L.E., 2012. Imported fire ants near the edge of their range: disturbance and moisture determine prevalence and impact of an invasive social insect. J. Anim. Ecol. 81, 884-895.

van Leeuwen, J., Raakjaer, J., van Hoof, L., van Tatenhove, J., Long, R., Ounanian, K., 2014. Implementing the Marine Strategy Framework Directive: a policy perspective on regulatory, institutional and stakeholder impediments to effective implementation. Mar. Policy 50, 325-330.

Levine, J.M., Vila, M., Antonio, C.M., Dukes, J.S., Grigulis, K., Lavorel, S., 2003. Mechanisms underlying the impacts of exotic plant invasions. Proc. R. Soc. Lond. B. Biol. Sci. 270, 775-781.

Lindeman, N., 2013. Subjectivized knowledge and grassroots advocacy: an analysis of an environmental controversy in northern California. J. Bus. Tech. Comm. 27, 62-90.

Linkov, I., Satterstrom, F.K., Kiker, G., Batchelor, C., Bridges, T., Ferguson, E., 2006. From comparative risk assessment to multi-criteria decision analysis and adaptive management: recent developments and applications. Environ. Int. 32, 1072-1093.

Liu, S., Cook, D., 2016. Eradicate, contain or live with it? Collaborating with stakeholders to evaluate responses to invasive species. Food Secur. 8, 49-59.

Lord Howe Island Community Liaison Group, 2013. Community Liaison group: minutes of third meeting. http://www.lhib.nsw.gov.au/sites/lordhowe/files/ public/images/documents/lhib/Environment/Rodent\%20Eradication/Minutes\% 20LHI\%20CLG\%20Meeting\%203.pdf.

Lorenzo, P., González, L., Reigosa, M.J., 2010. The genus Acacia as invader: the characteristic case of Acacia dealbata Link in Europe. Ann. For. Sci. 67, 101-101.
Mack, R.N., 2003. Global plant dispersal, naturalization, and invasion: pathways, modes and circumstances. In: Ruiz, G.M., Carlton, J.T. (Eds.), Invasive Species: Vectors and Management Strategies. Island Press, Washington, DC, pp. 3-30.

Le Maitre, D.C., Gaertner, M., Marchante, E., Ens, E., Holmes, P.M., Pauchard, A., O'Farrell, P.J., Rogers, A.M., Blanchard, R., Blignaut, J., Richardson, D.M., 2011. Impacts of invasive Australian acacias: implications for management and restoration. Divers. Distrib. 17, 1015-1029.

Malatinszky, Á., 2016. Stakeholder perceptions of climate extremes' effects on management of protected grasslands in a central european area. Weather, Climate, and Society 8, 209-217.

Malatinszky, Á., Ádám, S., Saláta-Falusi, E., Saláta, D., Penksza, K., 2013. Planning management adapted to climate change effects in terrestrial wetlands and grasslands. Int. J. Glob. Warming 5, 311-325.

Mangachena, J.R., Geerts, S., 2017. Invasive alien trees reduce bird species richness and abundance of mutualistic frugivores and nectarivores; a bird's eye view on a conflict of interest species in riparian habitats. Ecol. Res. 32 (5), 667-676.

Manktelow, J., 2009. Brainstorming Toolkit. Mindtools Ltd.

Marchante, H., Morais, M.C., Gamela, A., Marchante, E., 2016. Using a WebMapping platform to engage volunteers to collect data on invasive plants distribution. Trans. GIS. https://doi.org/10.1111/tgis.12198.

Marr, S.M., Impson, N.D., Tweddle, D., 2012. An assessment of a proposal to eradicate non-native fish from priority rivers in the Cape Floristic Region, South Africa. Afr. J. Aquat. Sci. 37, 131-142.

McConnachie, A.J., Strathie, L.W., Mersie, W., Gebrehiwot, L., Zewdie, K., Abdurehim, A., Abrha, B., Araya, T., Asaregew, F., Assefa, F., Gebre-Tsadik, R., 2011. Current and potential geographical distribution of the invasive plant Parthenium hysterophorus (Asteraceae) in eastern and southern Africa. Weed Res. 51, 71-84.

McConnachie, M.M., Richardson, D.M., Van Wilgen, B.W., Ferraro, P.J., Forsyth, T., 2015. Estimating the effect of plantations on pine invasions in protected areas: a case study from South Africa. J. Appl. Ecol. 52, 110-118.

McConnachie, M.M., van Wilgen, B.W., Ferraro, P.J., Forsyth, A.T., Richardson, D.M., Gaertner, M., Cowling, R.M., 2016. Using counterfactuals to evaluate the costeffectiveness of controlling biological invasions. Ecol. Appl. 26, 475-483.

McKinney, M., Field, P., 2008. Evaluating community-based collaboration on federal lands and resources. Soc. Nat. Resour. 21, 419-429.

Measey, J., Annecke, W., Davies, S., Dorse, C., Stafford, L., Tolley, K., Turner, A., 2014. Cape collaborations for amphibian solutions. FrogLog 109, 46-47.

Measey, G.J., Vimercati, G., de Villiers, F.A., Mokhatla, M.M., Davies, S.J., Edwards, S., Altwegg, R., 2015. Frog eat frog: exploring variables influencing anurophagy. PeerJ 3, e1204.

Measey, G.J., Vimercati, G., de Villiers, F.A., Mokhatla, M., Davies, S.J., Thorp, C.J., Rebelo, A.D., Kumschick, S., 2016. A global assessment of alien amphibian impacts in a formal framework. Divers. Distrib. 22, 970-981.

Measey, J., Davies, S., Vimercati, G., Rebelo, A., Schmidt, Turner, A.A., 2017. Invasive amphibians in southern Africa: a review of invasion pathways. Bothalia 47, a2117. https://doi.org/10.4102/abc.v47i2.2117.

Moon, K., Blackman, D.H., Brewer, T.D., 2015. Understanding and integrating knowledge to improve invasive species management. Biol. Invasions 17, 2675-2689.

Moran, V.C., Hoffmann, J.H., Donnelly, D., van Wilgen, B.W., Zimmermann, H., 2000 Biological control of alien, invasive pine trees (Pinus species) in South Africa. In: Spencer, N.R. (Ed.), Proceedings of the 5th International Symposium on Biological Control of Weeds, pp. 4-14.

Morris, J., Baddache, F., 2012. Back to basics: How to make stakeholder engagement meaningful for your company. The Business of a Better World.

Myers, J.H., Simberloff, D., Kuris, A.M., Carey, J.R., 2000. Eradication revisited: dealing with exotic species. Trends Ecol. Evol. 15, 316-320.

Naylor, R.L., Williams, S.L., Strong, D.R., 2001. Aquaculture-A gateway for exotic species. Science 294, 1655-1656.

Newcombe, R., 2003. From client to project stakeholders: a stakeholder mapping approach. Constr. Manage. Econ. 21, 841-848.

Novoa, A., Le Roux, J.J., Robertson, M.P., Wilson, J.R.U., Richardson, D.M., 2015a. Introduced and invasive cactus species: a global review. AoB Plants 7, pul078. https://doi.org/10.1093/aobpla/plu078.

Novoa, A., Kaplan, H., Kumschick, S., Wilson, J.R.U., Richardson, D.M., 2015b. Soft touch or heavy hand? Legislative approaches for preventing invasions: insights from cacti in South Africa. Invasive Plant. Sci. Manag. 8, 307-316.

Novoa, A., Kaplan, H., Wilson, J.R.U., Richardson, D.M., 2016. Resolving a prickly situation: involving stakeholders in invasive cactus management in South Africa. Environ. Manag. 57, 998-1008.

Olander, S., Landin, A., 2005. Evaluation of stakeholder influence in the implementation of construction projects. Int. J. Proj. Manag. 23, 321-328.

Peterson, G.D., Cumming, G.S., Carpenter, S.R., 2003. Scenario planning: a tool for conservation in an uncertain world. Conserv. Biol. 17, 358-366.

Ramshaw, L.A., 1989. A metaplan model for problem-solving discourse. In: Somers, H., McGee Wood, M. (Eds.), Proceedings of the Fourth Conference on European Chapter of the Association for Computational Linguistics. Association for Computational Linguistics, Stroudsburg, pp. 35-42.

Reed, M.S., 2008. Stakeholder participation for environmental management: a literature review. Biol. Conserv. 141, 2417-2431.

Reed, M.S., Curzon, R., 2015. Stakeholder mapping for the governance of biosecurity: a literature review. J. Integr. Environ. Sci. 11, 15-38.

Reed, M.S., Graves, A., Dandy, N., Posthumus, H., Hubacek, K., Morrie, J., Prell, C., Quinn, C.H., Stringer, L.C., 2009. Who's in and why? A typology of stakeholders 
analysis methods for natural resource management. J. Environ. Manag. 90, 1933-1949.

Richardson, D.M., Wilson, J.R.U., Weyl, O.L.F., Griffiths, C.L., 2011. South Africa: invasions. In: Simberloff, D., Rejmánek, M. (Eds.), Encyclopedia of Biological Invasions. University of California Press, Berkeley, pp. 643-651.

Robinson, T.B., Griffiths, C.L., McQuaid, C.D., Rius, M., 2005. Marine alien species of South Africa - status and impacts. Afr. J. Marine Sci. 27, 297-306.

Rout, T.M., Moore, J.L., McCarthy, M.A., 2014. Prevent, search or destroy? A partially observable model for invasive species management. J. Appl. Ecol. 51, 804-813.

Russell, J.C., Towns, D.R., Clout, M.N., 2008. Review of rat invasion biology: implications for island biosecurity. Sci. Conserv. 286, 1-53.

Scholes, R.J., Schreiner, G., Snyman-Van der Walt, L., 2017. Scientific assessments: matching the process to the problem. Bothalia 47 (2), 1-9. https://doi.org 10.4102/abc.v47i2.2144 a2144.

Scott, J., 2012. Social Network Analysis, third ed. Sage Publications Ltd.

Shackleton, C.M., Shackleton, R.T., 2016. Knowledge, perceptions and willingness to control designated invasive tree species in urban household gardens in South Africa. Biol. Invasions 6, 1599-1609.

Shackleton, C.M., McGarry, D., Fourie, S., Gambiza, J., Shackleton, S.E., Fabricius, C., 2007. Assessing the effects of invasive alien species on rural livelihoods: case examples and a framework from South Africa. Hum. Ecol. 35, 113-127.

Shackleton, R.T., Le Maitre, D.C., Pasiecznik, N.M., Richardson, D.M., 2014. Prosopis: a global assessment of the biogeography, benefits, impacts and management of one of the world's worst woody invasive plant taxa. AoB Plants 6, plu027. https://doi.org/10.1093/aobpla/plu027.

Shackleton, R.T., Le Maitre, D.C., Richardson, D.M., 2015. Stakeholder perceptions and practices regarding Prosopis (mesquite) invasions and management in South Africa. Ambio 44, 569-581.

Shackleton, R.T., Le Maitre, D.C., van Wilgen, B.W., Richardson, 2017. Towards a national strategy to optimise the management of a widespread invasive tree (Prosopis species; mesquite) in South Africa. Ecosyst. Serv. https://doi.org 10.1016/j.ecoser.2016.11.022.

Sharp, R.L., Larson, L.R., Green, G.T., 2011. Factors influencing public preferences for invasive alien species management. Biol. Conserv. 144, 2097-2104.

Stanley, M.C., Fowler, S.V., 2004. Conflicts of interest associated with the biologica control of weeds. In: XI International Symposium on Biological Control of Weeds, p. 322.

Stokes, K.E., O'Neill, K.P., Montgomery, W.I., Dick, J.T.A., Maggs, C.A., McDonald, R.A., 2006. The importance of stakeholder engagement in invasive species management: a cross-jurisdictional perspective in Ireland. Biodivers. Conserv. 15, 2829-2852.

Taylor, G.C., Weyl, O.L., Cowley, P.D., Allen, M.S., 2015. Dispersal and population- level mortality of Micropterus salmoides associated with catch and release tournament angling in a South African reservoir. Fish. Res. 162, 37-42.

te Beest, M., Esler, K.J., Richardson, D.M., 2015. Linking functional traits to impacts of invasive plant species: a case study. Plant Ecol. 216, 293-305.

Touza, J., Pérez-Alonso, A., Chas-Amil, M.L., Dehnen-Schmutz, K., 2014. Explaining the rank order of invasive plants by stakeholder groups. Ecol. Econ. 105, $330-341$.

Urgenson, L.S., Prozesky, H., Esler, K.J., 2013. Stakeholder perceptions of an ecosystem services approach to clearing invasive alien plants on private land. Ecol. Soc. 18, 26

van Wilgen, B.W., Richardson, D.M., 2014. Challenges and trade-offs in the management of invasive alien trees. Biol. Invasions 16, 721-734. https://doi.org/ 10.1007/s10530-013-0615-8.

Vimercati, G., Davies, S.J., Hui, C., Measey, J., 2017. Integrating age structured and landscape resistance models to disentangle invasion dynamics of a pondbreeding anuran. Ecol. Model. 356, 104-116.

Vreysen, M.J., Robinson, A.S., Hendrichs, J., 2007. Area-wide Control of Insect Pests: from Research to Field Implementation. Springer, Dordrecht.

Walker, D.H., Bourne, L.M., Shelley, A., 2008. Influence, stakeholder mapping and visualization. Constr. Manage. Econ. 26, 645-658.

Weyl, O.L.F., Finlayson, B., Impson, D., Woodford, D.J., 2014. Threatened endemic fishes in South Africa's Cape floristic region: a new beginning for the rondegat river. Fisheries 39, 270-279.

Weyl, O.L., Ellender, B.R., Wasserman, R.J., Woodford, D.J., 2015. Unintended consequences of using alien fish for human benefit in protected areas. Koedoe 57, 1.

van Wilgen, B.W., Richardson, D.M., 2012. Three centuries of managing introduced conifers in South Africa: benefits, impacts, changing perceptions and conflict resolution. J. Environ. Manag. 106, 56-68.

van Wilgen, B.W., Dyer, C., Hoffmann, J.H., Ivey, P., Le Maitre, D.C., Moore, J.L., Richardson, D.M., Rouget, M., Wannenburgh, A., Wilson, J.R., 2011. Nationalscale strategic approaches for managing introduced plants: insights from Australian acacias in South Africa. Divers. Distrib. 17, 1060-1075.

Williams, B.K., 2011. Adaptive management of natural resources - framework and issues. J. Environ. Manag. 92, 1346-1353.

Wilson, J.R., Panetta, J.D., Lindgren, C., 2017. Detecting and Responding to Alien Plant Incursions. Cambridge University Press, Cambridge.

de Wit, M.P., Crookes, D.J., van Wilgen, B.W., 2001. Conflicts of interest in environmental management: estimating the costs and benefits of a tree invasion. Biol. Invasions 3, 167-178.

Woodford, D.J., Richardson, D.M., MacIsaac, H.J., Mandrak, N.E., van Wilgen, B.W., Wilson, J.R.U., Weyl, O.L.F., 2016. Confronting the wicked problem of managing biological invasions. NeoBiota 30, 63-86. 